\title{
Ontogeny of Epidermal Growth Factor, Transforming Growth Factor- $\alpha$, Epidermal Growth Factor Receptor, and Thyroid Hormone Receptor RNA Levels in Rat Kidney and Changes in Those Levels Induced by Early Thyroxine Treatment
}

\author{
DANIEL NORTH, JAYARAMAN LAKSHMANAN, ANITA REVICZKY, MATHEW KASER, AND \\ DELBERT A. FISHER \\ Department of Pediatrics, UCLA Medical Center, Torrance, California 90509
}

\begin{abstract}
Ontogenic changes in the mRNA levels of epidermal growth factor (EGF), transforming growth factor- $\alpha$, EGF receptor, and thyroid hormone receptor ( $r$ erbA) were examined in developing rat kidneys. The mRNA levels of both EGF and thyroid hormone receptor rose dramatically during the postnatal period with the rise in thyroid hormone receptor message preceding the rise in EGF message. In addition, we examined renal mRNA levels in 1-wk-old rats treated with thyroxine $\left(T_{4}\right)$ from birth through $d 6$. Neonatal $T_{4}$ treatment augmented the renal mRNA levels of EGF but decreased the levels of EGF-receptor and transforming growth factor- $\alpha$. $\mathbf{T}_{4}$ treatment did not significantly affect the levels of renal mRNA for thyroid hormone receptor. Although the EGF and transforming growth factor- $\alpha$ peptides are similar and interact with the same receptor, our findings indicate that these homologous growth factors are regulated differently during development. In addition, hormones that influence growth and development, such as $T_{4}$, may function both as positive and negative regulators of growth factor expression. (Pediatr Res 31: 330-334, 1992)
\end{abstract}

\section{Abbreviations}

EGF, epidermal growth factor

TGF- $\alpha$, transforming growth factor- $\alpha$

EGF-R, epidermal growth factor receptor

SSC, saline sodium citrate

$T_{3}$, triiodothronine

$T_{4}$, thyroxine

poly $\mathrm{A}+$, polyadenylated

Rat EGF and TGF- $\alpha$ are polypeptide growth factors that share $40 \%$ amino acid sequence homology $(1,2)$. In vitro, both growth factors function as mitogens as well as differentiation factors for a wide variety of epithelial cells, and in vivo they accelerate several developmental processes such as tooth eruption and eyelid opening (2-4). Tooth eruption and eyelid opening can also be elicited by administration of thyroid hormones to new-

Received July 30, 1991; accepted November 18, 1991.

Correspondence and reprint requests to: J. Lakshmanan, Ph.D., RB-1 HarborUCLA Medical Center, 1000 W. Carson Street, Torrance, CA 90509.

Supported by National Institutes of Health Grant HD-04270. born rodents $(5,6)$, and it has been proposed that EGF mediates these developmental effects of thyroid hormone (7).

Thyroid hormones also have been shown to increase EGF as well as EGF mRNA levels in developing rodent kidneys (8). To more fully understand the interrelations among these polypeptide growth factors and thyroid hormones in developing rodent kidney, cDNA probes for EGF, TGF- $\alpha$, EGF-R, and thyroid hormone receptor $(\mathrm{r}$-erbA- $\beta$ ) were used to examine normal rat kidneys taken from animals ranging in age from $21 \mathrm{~d}$ postconception to adult. Northern blots were prepared and used to quantify changes in the relative amount of each message during development. The ontogenic changes in message levels were examined with respect to the normal postnatal increase in $T_{4}$ secretion. In addition, newborn animals were injected with $\mathrm{T}_{4}$ for the first $6 \mathrm{~d}$ of life to prematurely increase circulating adult $\mathrm{T}_{4}$ levels. Northern blots prepared from the kidneys of treated and control animals were examined to determine the effect of $\mathrm{T}_{4}$ treatment on the message levels of EGF, TGF- $\alpha$, EGF receptor, and thyroid hormone receptor.

\section{MATERIALS AND METHODS}

Sprague-Dawley rats were obtained from Simonson Laboratories. Date-bred rats from the same source provided the fetal and neonatal animals used in the study. The animals were maintained in accordance with the NIH Guide for the Care and Use of Laboratory Animals. For the $\mathrm{T}_{4}$ treatment studies, newborn rats were treated with $\mathrm{T}_{4}(0.4 \mu \mathrm{g} / \mathrm{g}$ body wt/d) from the day of birth through d 6 of life; kidneys were collected on d 7. After decapitation, rat kidney tissues were removed, quickly frozen in a bath of liquid nitrogen, and stored at $-70^{\circ} \mathrm{C}$. Before RNA extraction, the pooled kidney tissue was again placed in liquid nitrogen and ground into a coarse powder with a mortar and pestle. RNA was extracted from $100 \mathrm{mg}$ of the powder using RNAzol (CINNA-BIOTECX, TX). Each extraction yielded about $100 \mu \mathrm{g}$ of total RNA as assayed by absorbance at $260 \mathrm{~nm}$. Poly A+ RNA was subsequently prepared by passage of the total RNA preparations over oligo-dT columns; $0.5-1.0 \mathrm{mg}$ of total RNA was passed through 1-mL oligo-dT columns, and poly A+ RNA was eluted with $10 \mathrm{mM}$ Tris (pH 7.2) and $0.3 \%$ SDS as described by Gielen et al. (9).

To produce Northern blots, $1-3 \mu \mathrm{g}$ of poly A+ RNA (or 10$15 \mu \mathrm{g}$ of total RNA) was denatured with glyoxal (50\% DMSO, 1 $\mathrm{M}$ glyoxal, $10 \mathrm{mM} \mathrm{NaH} \mathrm{PO}_{4}, \mathrm{pH} \mathrm{7.0)}$ for $15 \mathrm{~min}$ at $50^{\circ} \mathrm{C}$ and electrophoresed on $1 \%$ agarose gels as described by Maniatis et al. (10). Total RNA gels were examined for the presence of 
ribosomal RNA bands and poly A+ gels for the absence of ribosomal RNA bands by staining the gels for $15 \mathrm{~min}$ in $0.5 \mu \mathrm{g} /$ $\mathrm{mL}$ ethidium bromide and then viewing the gels on a UV transilluminator. The RNA was then blotted for $12-20 \mathrm{~h}$ to nylon membranes $(\mathrm{MSI})$ with $20 \times \mathrm{SSC}$. These conditions were sufficient to transfer both of the ethidium-stained ribosomal RNA bands from the total RNA gels to the filters. Blots were baked for $2 \mathrm{~h}$ at $80^{\circ} \mathrm{C}$ before hybridization.

Probes specific to four RNA transcripts were used in these experiments. In addition, a single-stranded oligo-dT probe was used to assay for loading inequities on the poly $\mathrm{A}+$ blots. The EGF probe consisted of a 3.3-kb EcoRI fragment of the rat EGF precursor cDNA (11). The TGF- $\alpha$ probe was a $2.3-\mathrm{kb} E c o$ RI fragment of the rat TGF- $\alpha$ cDNA described by Blasbland et al. (12). The EGF-R probe was a 2.2-kb EcoRI cDNA fragment that encodes the entire extracellular domain of the rat EGF-R (13). The thyroid hormone receptor probe was a $1.44-\mathrm{kb}$ PstI fragment taken from the $5^{\prime}$ coding region of r-erbA- $\beta$ (14). The oligo-dT probe (Sigma Chemical Co., St. Louis, MO) was a single-strand polymer 14-22 bases in length.

The gene-specific DNA probes were labeled using ${ }^{32} \mathrm{P}$-deoxycytidine triphosphate, random primers, and Klenow fragment (Multiprime; Amersham, Arlington Heights, IL). Typically, 50 ng of fragment yielded $4-8 \times 10^{7}$ of precipitable counts, which were used for individual hybridizations. The oligonucleotide probe, polythymidilic acid, was $5^{\prime}$ end-labeled with $\gamma-{ }^{32}$ P-ATP and polynucleotide kinase (New England Nuclear, Boston, MA); typically, $32 \mathrm{pmol}$ of the oligonucleotide were labeled to 2-4 $\times$ $10^{6} \mathrm{cpm} / \mathrm{pmol}$ and the entire yield was used in hybridizations.

Hybridization and washing conditions were those described by the membrane manufacturer (MSI) for perfect hybrids. Prehybridizations were $4 \mathrm{~h}$ at $42^{\circ} \mathrm{C}$ in $50 \%$ formamide, $5 \times$ Denhardt's, $5 \times$ SSPE (sodium chloride, sodium phosphate, EDTA), $0.1 \%$ SDS, and $200 \mu \mathrm{g} / \mathrm{mL}$ carrier DNA. Hybridizations were overnight at $42^{\circ} \mathrm{C}$ in $50 \%$ formamide, $5 \times$ Denhardt's, $5 \times$ SSPE, $0.1 \%$ SDS, $5 \%$ dextran sulfate, and $200 \mu \mathrm{g} / \mathrm{mL}$ carrier DNA. Hybridization was followed by three washes in $2 \times \mathrm{SSC}, 5 \mathrm{~min}$ each at $22^{\circ} \mathrm{C}$; two washes in $2 \times \mathrm{SSC}$ and $0.5 \% \mathrm{SDS}, 15 \mathrm{~min}$ each at $50^{\circ} \mathrm{C}$; and two washes in $0.1 \times \mathrm{SSC}$ for $5 \mathrm{~min}$ each at $22^{\circ} \mathrm{C}$. When it was necessary to rehybridize a blot with a second probe, the blot was heated to $70^{\circ} \mathrm{C}$ in $500 \mathrm{~mL}$ of $5 \mathrm{mM}$ Tris, $\mathrm{pH}$ $8.0,0.2 \mathrm{mM}$ EDTA, $0.5 \%$ pyrophosphate, and $0.1 \times$ Denhardt's for $2 \mathrm{~h}$ to remove any remaining undecayed probe.

Autoradiographs were made by using the blots to expose Kodak X-Omat film at $-70^{\circ} \mathrm{C}$. Densitometry was performed and analyzed using a video densitometer (model 620; Bio-Rad Laboratories, Richmond, CA) and IDPACK software.

Because of the marked developmental change in the amount of EGF RNA in the neonatal rat kidney, it was not practical to use densitometry to quantify relative mRNA levels at various ages. Thus, blots were autoradiographed to determine the exact location of the lanes. The lanes were then cut out, immersed in scintillation cocktail, and counted.

\section{RESULTS}

RNA was extracted from the kidneys of rats ranging in age from $21 \mathrm{~d}$ postconception to over $80 \mathrm{~d}$ postconception (birth occurs at $22 \mathrm{~d}$ postconception). Equal amounts of RNA from each age were sized on agarose gels, and Northern blots were prepared. Figure 1 shows a sequence generated from total RNA. The ethidium bromide-stained gel shown in Figure 1A provides visual assurance that all lanes were loaded evenly. A blot prepared from the gel shown in Fig. $1 \mathrm{~A}$ was hybridized with a probe for rat EGF. As shown in Figure $1 B$, there is a large increase in the amount of rat kidney EGF RNA during the postnatal period, with the majority of the increase occurring between $\mathrm{d} 9$ and 15 . The blot shown in Figure $1 B$ was washed and reprobed with a probe for rat thyroid hormone receptor; the result is shown in Figure $1 C$. Again, the relative amount of message shows a clear

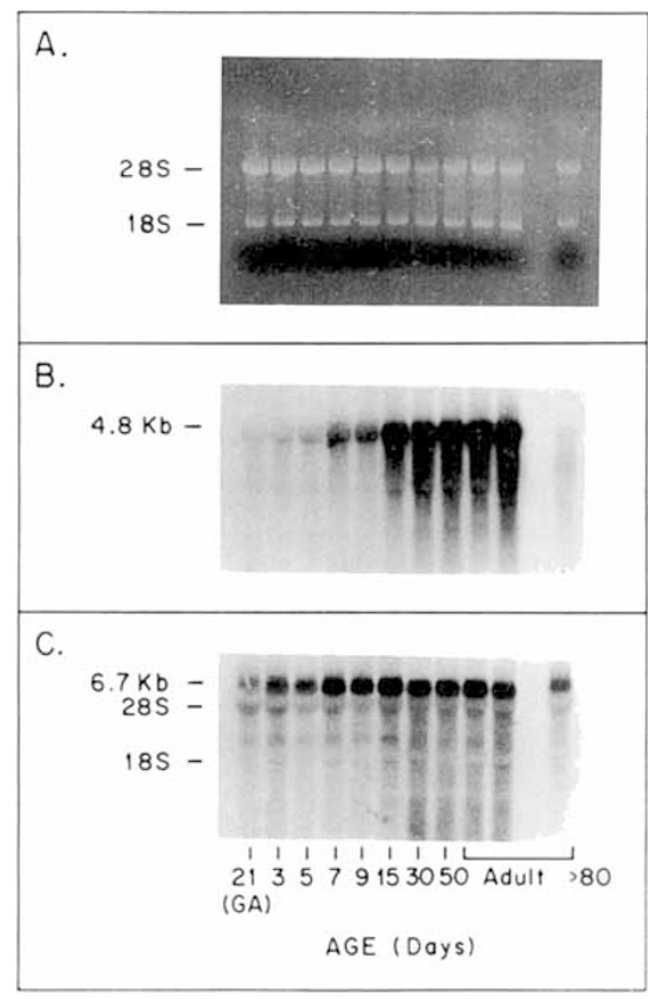

Fig. 1. Hybridization of rat EGF and thyroid hormone receptor probes with a Northern blot of rat kidney RNA collected at various ages. Twelve $\mu \mathrm{g}$ of total rat kidney RNA collected at the indicated ages and rat liver RNA were electrophoresed on a $1 \%$ agarose gel. The ethidium bromide-stained gel is shown in $A$. The gel was blotted to a nylon filter and sequentially hybridized with two different probes: $B$, hybridization with an EGF probe, and $C$, hybridization with a thyroid hormone receptor probe $(r-e r b A-\beta)$.

increase during the early postnatal period. Blots similar to those shown in Figure 1 were also hybridized with both rat TGF- $\alpha$ and rat EGF-R probes. Hybridizations with either probe could only be visualized after relatively long exposures, and no changes in the levels of these messages were observed (data not shown).

Rat liver RNA was included on the kidney ontogeny blots for comparison. Although the levels of EGF-R message remained constant in developing rat kidney, the amount of EGF message in rat kidney was much less than that in rat liver. In addition, the pattern of hybridization in kidney was different from that in liver. Figure 2 compares equivalent amounts of poly A+ RNA from kidney and liver. Four species $(9.6,6.5,5.0$, and $2.7 \mathrm{~kb})$ of EGF-R RNA have been reported in liver, with the $2.7-\mathrm{kb}$ band being predominant (13). The 2.7-kb band is of interest because it encodes a truncated EGF-R; proteins produced from this transcript would lack the transmembrane region. All four EGF receptor RNA species were significantly lower in kidney compared with liver. Also, the 2.7-kb band is the most prominent band in liver, whereas it is relatively reduced in kidney.

Data from blots examined with probes for EGF and thyroid hormone receptor (Fig. 1) were compiled and plotted in Figure 3 . The message levels were compared with the normal developmental increase in serum $\mathrm{T}_{4}$ concentration (15). TGF- $\alpha$ and EGF-R message levels do not change during postnatal development (data not shown). The graph shows that the relative amounts of message for both EGF and thyroid hormone receptor rise rapidly in rat kidney after birth, and, for both, most of the increase occurs during the $2 \mathrm{nd}$ wk of life. The increase in thyroid hormone receptor RNA levels precedes the increase in rat serum $\mathrm{T}_{4}$ levels. EGF message levels also increase rapidly at nearly the same time as serum $\mathrm{T}_{4}$ levels, but rather than reaching a plateau they continue to increase, at a reduced rate, after $30 \mathrm{~d}$ of age. 


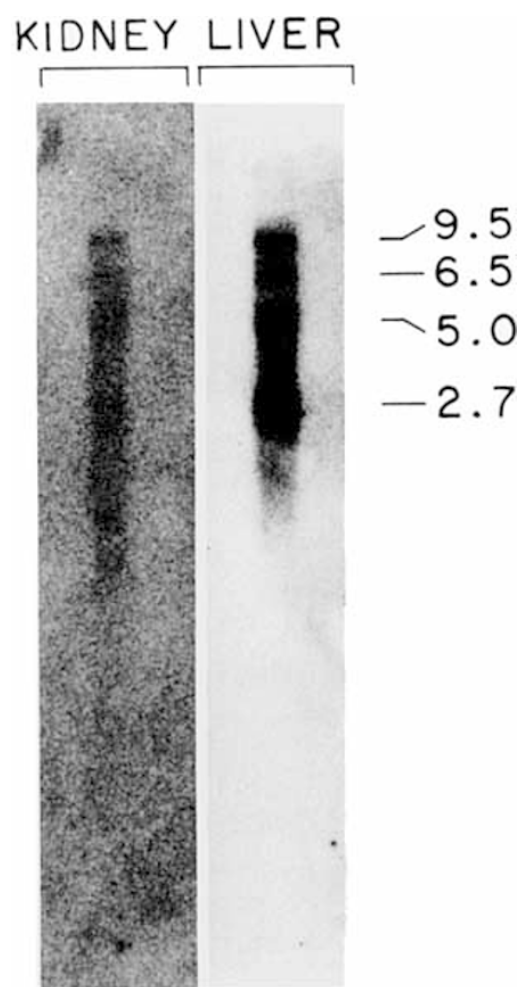

Fig. 2. EGF-R message levels in kidney and liver. Equal amounts of polyA+ RNA from rat kidney and rat liver were electrophoresed on a $1.2 \%$ agarose gel, blotted to nylon, and probed with an EGF-R-specific probe.

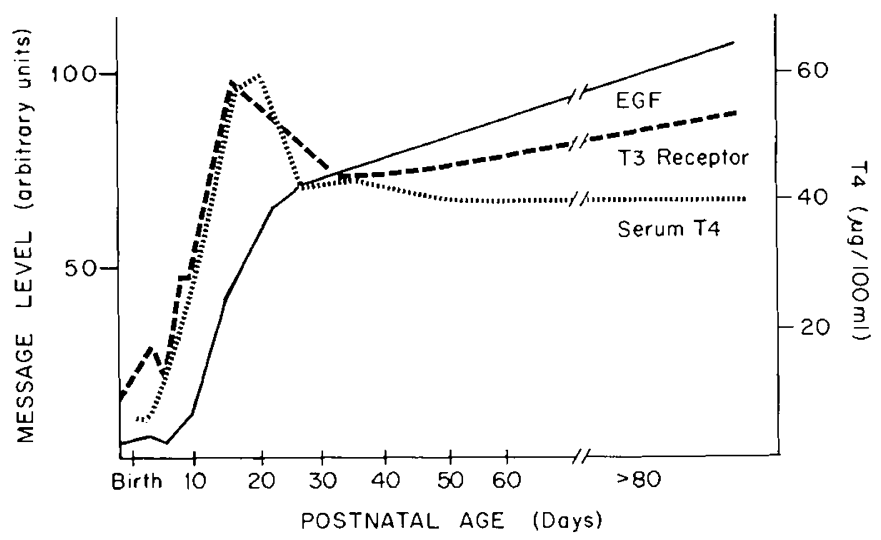

Fig. 3. Densitometry of the Northern blots shown in Figure 1. Changes in the levels of EGF and thyroid hormone receptor RNA are plotted as a function of the age at which the RNA was collected (units on the $y$ axis are arbitrary). For comparison, rat serum $T_{4}$ levels have also been plotted as a function of age (15).

To further examine the relationship between serum $T_{4}$ levels and the levels of the respective messages in developing rat kidney, $\mathrm{T}_{4}$ was injected into newborn rats during the first $6 \mathrm{~d}$ of life and the kidneys were examined on $\mathrm{d} 7$. The $\mathrm{T}_{4}$ dose was sufficient to raise the neonatal serum $T_{4}$ levels to adult values (16). This represents an overall increase in serum $T_{4}$ concentration in the 7-d-old animals of about 5-fold. A comparison of the various message levels in control and $\mathrm{T}_{4}$-treated rat kidneys is shown in Figure 4. Although there was a significant increase in the EGF message levels in the treated animals, the increase was less than 3-fold. During normal development, the increase in EGF levels between $\mathrm{d} 7$ and $\mathrm{d} 30$ is 8 -fold. EGF-R and TGF- $\alpha$ message levels showed decreases that were significant at $p<0.01$. The decrease in thyroid hormone receptor message level was not significant.
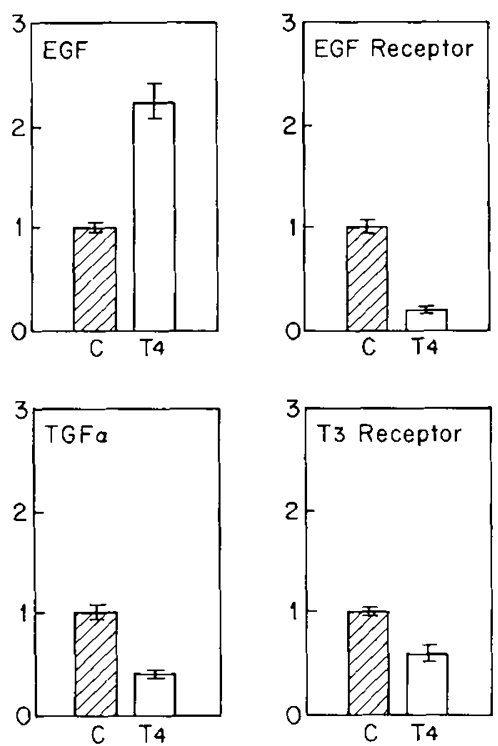

Fig. 4. Changes in message levels of 7-d-old rats after $6 \mathrm{~d}$ of $T_{4}$ treatment. Newborn rats were injected daily, for $6 \mathrm{~d}$, with either $T_{4}$ or vehicle; the kidneys were removed on $\mathrm{d} 7$. RNA was extracted and Northern blots were prepared. The blots were hybridized with the indicated probes. Differences in hybridization intensities were quantified by densitometry and plotted. The values have been normalized so that all controls have a value of 1 . For all bars $n=4$, and the results are presented as mean $\pm \mathrm{SEM}$.

\section{DISCUSSION}

Previously, we localized EGF and TGF- $\alpha$ in rat kidney tubular epithelial cells (17), and in the current study we have shown that renal EGF mRNA levels are characterized by three ontogenic phases: low levels between fetal d 21 and postnatal d 5, a 6-fold increase between $\mathrm{d} 7$ and 21 , and a further 2 -fold increase between $\mathrm{d} 21$ and 60 . These quantitative changes are similar to EGF mRNA ontogenic changes previously observed in mouse kidney (18). In rats, a rapid increase in serum $T_{4}$ occurs during the $2 \mathrm{nd}$ wk of life (15). This, along with the ability of injected $\mathrm{T}_{4}$ to prematurely increase renal EGF mRNA expression in neonatal rats, suggests that the normal postnatal increase in EGF RNA may be regulated by circulating thyroid hormones. This is supported by the finding of a $\mathrm{T}_{4}$-responsive element at the $5^{\prime}$ end of cloned mouse EGF cDNA (19). This postulated effect of $\mathrm{T}_{4}$ on renal EGF production would require that thyroid hormone receptors be present in kidney tissue on or before $d 7$. The present results indicate that thyroid hormone receptor message levels have reached about $25 \%$ of the maximal value by $\mathrm{d} 7$. We examined only the message levels for $\mathrm{r}-\operatorname{erbA}-\beta$; there is a second form of thyroid hormone receptor, $r-\operatorname{erbA}-\alpha(20)$, that could potentially contribute to available receptors in the developing kidney. The r-erbA- $\alpha$ mRNA levels were not examined because the message levels are relatively low compared with those of $\mathrm{r}-$ erbA- $\beta$, and it has been shown that the r-erbA- $\beta$ message levels better correlate with nuclear $T_{3}$ binding in kidney tissue (21).

In rats, a rapid phase of renal growth (i.e. cell division) occurs between fetal life and postnatal d 15 (22), and functional maturation (i.e. differentiation) has been observed between postnatal d 12 and $30(23,24)$. The lack of significant changes in EGF mRNA expression during the rapid growth phase and the large increase in EGF message that accompanies the period of maturational changes suggest that the translated precursor or the precursor-derived proteins may play an important role in renal tubular functional maturation. In rat as well as mouse and human kidneys, EGF immunoreactivity is localized to the apical membrane of the tubular cell, suggesting that the peptide is synthesized and stored as a transmembrane precursor protein (25). Preliminary investigations also show that rat kidney is 
similar to mouse and human kidney in that it secretes proEGF and partially processed high molecular weight EGF into urine (26). Whether the precursor or processed proteins function as maturation factors is presently under investigation in this laboratory.

Only a small amount of TGF- $\alpha$ mRNA is found in kidney extracts, and, in contrast to EGF mRNA, the TGF- $\alpha$ mRNA levels were constant in all age groups studied. The lack of ontogenic changes in TGF- $\alpha$ mRNA concentrations was unexpected because we have observed age-dependent changes in renal TGF- $\alpha$ immunoreactivity (27). This peptide-mRNA discrepancy could relate to mRNA stability, protein storage pools, or developmental changes in the renal TGF- $\alpha$ precursor processing enzyme(s). At present, little information is available on the processing of proTGF- $\alpha$ in vivo.

$\mathrm{T}_{4}$ treatment of newborn rats increased the levels of EGF message but caused a significant decrease in the level of TGF- $\alpha$ message. In rat kidney, TGF- $\alpha$ is expressed in the cortical collecting tubular cells (17). The differential effects of $T_{4}$ on EGF and TGF- $\alpha$ messages suggest that $T_{4}$ may have distinct effects on different nephron segments that express specific growth factors. Although the $5^{\prime}$ flanking region of the TGF- $\alpha$ gene does not contain a thyroid hormone responsive element, a recent study reported a stimulatory effect of $\mathrm{T}_{3}$ on TGF- $\alpha$ mRNA expression in human mammary carcinoma cells (28). The observed decreases in renal TGF- $\alpha$ message levels in $\mathrm{T}_{4}$-treated animals suggest that inhibition may be mediated by other factors. The possibility that proEGF or its processed proteins participate in the inhibition cannot be ruled out inasmuch as these growth factors, in urine, are expected to make contact with cortical collecting tubular cells.

In the present study, we observed that EGF-R mRNA is present in rat kidneys at a low, constant level during the fetal, neonatal, and adult stages of development. There have been no previous investigations regarding the ontogeny of renal EGF-R mRNA in any species. However, renal EGF-R distribution has been investigated in mouse, rat, rabbit, and man (29-34). Radioactive ligand binding studies in mice indicate that EGF-R are present only during a restricted period of fetal development (29). In contrast, both ligand-binding studies and biologic response studies in rats and rabbits provide evidence for the presence of EGF-R in adult kidneys $(30,31)$. Ligand-binding studies with human fetal kidney membranes and the presence of EGF-R mRNA in adult human kidney suggest that EGF-R are present during both fetal and adult stages of development $(32,33)$.

$\mathrm{T}_{4}$ treatment of 1-wk-old rats caused a significant decrease in EGF-R mRNA expression. $\mathrm{A} \mathrm{T}_{3}$ receptor element in the EGF-R $5^{\prime}$ promoter region has recently been identified, and negative regulation by ligand-activated $\mathrm{T}_{3}$ receptor has been reported (35). The observed inhibitory response in this study is consistent with the reported inhibitory role of thyroid hormones in EGF-R expression.

Finally, with respect to possible feedback controls of EGF and EGF-R synthesis, it is interesting to note that in both kidney and liver tissue there is an inverse relationship between the level of EGF and EGF-R messages. In adult rats, EGF message levels in kidney are high compared with those in liver. The opposite is true with the EGF-R message; levels are low in kidney and high in liver. These data suggest that EGF synthesized in a tissue may not act directly on EGF-R in the same tissue. A mechanism or mechanisms may exist that prevent the colocalization of EGF and EGF-R, thereby limiting the possibility of uncontrolled cell proliferation.

Acknowledgments. The authors thank the following people for providing the rat cDNA clones that were used to make probes: Donna S. Dorow for rat EGF, H. Shelton Earp for rat EGF-R, David C. Lee for rat TGF- $\alpha$, and Howard C. Towle for r-erbA- $\beta$.

\section{REFERENCES}

1. Marquardt H, Hunkapillar MW, Hood LE, Todaro GJ 1984 Rat transforming growth factor type 1: structure and relation to epidermal growth factor. Science 233:1079-1082

2. Fisher DA, Lakshmanan J 1990 Metabolism and effects of epidermal growth factor and related growth factors in mammals. Endocr Rev 11:418-442

3. Derynck R 1986 Transforming growth factor-alpha: structure and biological activities. J Cell Biochem 32:293-304

4. Smith JM, Sporn MB, Roberts AB, Derynck ME, Winkler ME, Gregory H 1985 Human transforming growth factor causes precocious eyelid opening in newborn mice. Nature 315:515-516

5. Khamsi F, Eayrs JT 1966 A study of the effects of thyroid hormones on growth and development. Growth 30:143-150

6. Schapiro $S 1968$ Some physiological, biochemical and behavioral consequences of neonatal hormone administration of cortisol and thyroxine. Gen Comp Endocrinol 10:214-228

7. Hoath SB, Lakshmanan J, Scott SM, Fisher DA 1983 Effect of thyroid hormones on epidermal growth factor concentration in neonatal mouse skin. Endocrinology 112:308-314

8. Salido EC, Lakshmanan J, Koy S, Barajas L. Fisher DA 1990 Effect of thyroxine administration on the expression of epidermal growth factor in the kidney and submandibular gland of neonatal mice. An immunocytochemical and in situ hybridization study. Endocrinology 127:2263-2269

9. Gielen J, Aviv H, Leder P 1974 Characteristics of rabbit globin mRNA purification by oligo(dT) cellulose chromatography. Arch Biochem Biophys 163:146-154

10. Maniatis T, Fritsch EF, Sambrook J 1982 Molecular Cloning: A Laboratory Manual. Cold Spring Harbor Laboratory, Cold Spring Harbor, NY

11. Dorow DS, Simpson RJ 1988 Cloning and sequence analysis of a cDNA for rat epidermal growth factor. Nucleic Acids Res 16:9338

12. Blasband AJ, Rogers KT. Chen X, Azizkhan JC, Lee DC 1990 Characterization of the rat transforming growth factor alpha gene and identification of promoter sequences. Mol Cell Biol 10:2111-2117

13. Petch LA, Harris J, Raymond VW, Blasbland A, Lee DC, Earp HS 1990 A truncated, secreted form of the epidermal growth factor receptor is encoded by an alternatively spliced transcript in normal rat tissue. Mol Cell Biol 10: $2973-2982$

14. Murray MB, Zilz ND, McCreary NL, MacDonald MJ. Towle HC 1988 Isolation and characterization of rat cDNA clones for two distinct thyroid hormone receptors. J Biol Chem 263:12770-12777

15. Dussaullt JH, Labrie F 1975 Development of the hypothalamic-pituitarythyroid axis in the neonatal rat. Endocrinology 97:1321-1324

16. Lakshmanan J, Perheentupa J, Alm J, Fisher DA 1986 Neonatal hyperthyroidism in mice has different effects on epidermal growth factor levels in submandibular gland, urine, and blood. Pediatr Res 20:628-631

17. Salido EC, Lakshmanan J, Brown P, Odell W, Barajas L. Fisher DA 1990 Differential cellular localization of EGF and TGF-alpha in the rat kidney. Clin Chem 38:208A (abstract)

18. Lakshmanan J, Reviczky A, North D, Salido EC, Fisher DA 1990 Ontogenic changes and thyroxine responsiveness of renal epidermal growth factor prohormone mRNA correlate with developmental changes and T4-stimulated increase in urinary-EGF excretion in mice. Clin Res 38:171 A(abstr)

19. Pascall JC, Brown KD 1988 Structural analysis of the 5 -flanking sequence of the mouse epidermal growth factor gene. J Mol Endocrinol 1:5-11

20. Thompson CC, Weinberger C, Lebo R, Evans RM 1987 Identification of a novel thyroid hormone receptor expressed in the mammalian central nervous system. Science 237:1610-1614

21. Strait KA, Schwartz HL, Perez-Castillo A, Oppenheimer JH 1990 Relationship of c-erbA mRNA content to tissue triiodothyronine nuclear binding capacity and function in developing and adult rats. J Biol Chen 265:10514-10521

22. Holthofer H 1987 Ontogeny of cell type specific enzyme reactivities in kidney collecting ducts. Pediatr Res 22:504-508

23. Edwards BR, Mendel DB, LaRochelle Jr FT, Stern P, Valtin H 198 I Postnatal development of urinary concentrating ability in rats: changes in renal antatomy and neurohypophysial hormones. In: Spitzer A (ed) The Kidney During Development. Masson Publishing, New York, pp 233-240

24. Rane S, Asperia A, Eneroth P, Lundin S 1985 Development of urinary concentrating capacity in weanling rats. Pediatr Res 19:472-475

25. Salido EC, Lakshmanan J, Fisher DA. Shapiro LJ, Barajas L 1991 Expression of epidermal growth factor in the rat kidney. An immunocytochemical and in situ hybridization study. Histochemistry 95:65-72

26. Lakshmanan J, Salido EC, Lam R, Barajas L, Fisher DA 1991 Secretion of epidermal growth factor precursor and high molecular weight epidermal growth factor proteins in adult rat urine. Endocrine Society Program, abstr A473

27. Brown P, Lam R, Lakshmanan J, Fisher DA 1990 Transforming growth factor alpha (TGF-alpha) in the developing rat. Am J Physiol 22:E256-E260

28. Raja RJ, Paterson AJ, Shin TH, Kudlow JE 1991 Transcriptional regulation 
of the human transforming growth factor-alpha gene. Mol Endocrinol 5: $514-520$

29. Partanen AM. Thesleff I 1987 Localization and quantitation of epidermal growth factor binding in mouse embryonic tooth and other embryonic tissues at different developmental stages. Dev Biol 120:186-197

30. Harris RC, Daiel TO 1989 Epidermal growth factor binding, stimulation of phosphorylation and inhibition of gluconeogenesis in rat proximal tubule. $\mathrm{J}$ Cell Physiol 139:383-391

31. Breyer MD, Redha R, Bryer JA 1990 Segmental distribution of epidermal growth factor binding sites in rabbit nephron. Am J Physiol 259: F553-F558
32. Nexo E, Kryger-Baggesen N 1989 The receptors for epidermal growth factor is present in human fetal kidney, liver and lung. Regul Pept 26:1-8

33. Sargent ER, Gomella LG, Belldegrun A, Linehan W'M. Kasid A 1989 Epidermal growth factor receptor gene expression in normal human kidney and renal cell carcinoma. J Urol 142:1364-1368

34. Fisher DA, Salido EC, Barajas L 1989 Epidermal growth factor and the kidney. Annu Rev Physiol 51:67-80

35. Hudson LG. Santon JB, Glass CK. Gill GN 1990 Ligand-activated thyroid hormone and retinoic acid receptors inhibit growth factor receptor promoter expression. Cell $62: 1165-1175$

\section{Announcements}

\section{Meeting Announcement}

The Society for Behavioral Pediatrics will conduct its 10th Annual Scientific Meeting and Workshops on September 17-21, 1992 at the Hyatt Regency Hotel in St. Louis, MO. For further information and registration forms, please contact Ms. Noreen Spota at (215) 248-9168.

\section{NIH Treatment Study for Sydenham's Chorea}

Acutely ill patients with Sydenham's chorea are being sought for a controlled treatment study. Eligible patients will receive free diagnostic evaluation and treatment, including palliative medications, at the Child Psychiatry Branch of the National Institute of Mental Health in Bethesda, MD. The treatment study is an outgrowth of our long-term investigations of the sequelae of Sydenham's chorea. To participate, children should be at least $6 \mathrm{y}$ old and acutely ill. There will be no expense to the patient (all treatment, travel, and lodging will be free of cost) and no remuneration. To refer a patient, contact Dr. Susan Swedo at (301) 496-6081, Building 10, Room 6N240, 9000 Rockville Pike, Bethesda, MD 20892, FAX (301) 402-0296. 